\author{
Дударєв I.М. ${ }^{1}$, Хомич А.В. ${ }^{2}$, Герасимик-Чернова Т.П. ${ }^{2}$ \\ ${ }^{1}$ Луиький національний технічний університет, м. Луцьк, Украӥна \\ ${ }^{2}$ Любешівський технічний коледж Луцького НТУ, смт. Любешів, Україна
}

\title{
ТЕОРЕТИЧНЕ ДОСЛІДЖЕННЯ ПРОЦЕСУ БРАННЯ ЛЬОНУ КОНІЧНО-ДИСКОВИМ ЛЬОНОБРАЛЬНИМ АПАРАТОМ
}

\begin{abstract}
Технологія переробки льону на коротке волокно не вимагає паралельності стебел у стрічці. Це дозволяє спростити конструкцію льонобрального апарата. Теоретичне дослідження процесу брання льону новим конічно-дисковим льонобральним апаратом, що має просту конструкцію, дозволило отримати умови для обгрунтування його раціональних параметрів в залежності від стану і параметрів стеблостою льону. Отримано умови для визначення кутової швидкості обертання і висоти встановлення дисків та рівняння, що описують траєкторії руху частин стебла льону під час брання.

Ключові слова: льон-довгунець, льон олійний, брання льону, льонобральний апарат, збирання льону, льонозбиральна техніка.
\end{abstract}

Постановка проблеми. У відповідності до технології первинної переробки стеблової частини льону-довгунця та льону олійного на коротке волокно, немає потреби забезпечувати паралельність стебел льону під час їх обробки. Відповідно, під час збирання льону також не потрібно забезпечувати паралельність стебел у стрічці (валку). За традиційної технології збирання льону основною вимогою, що висувалася до льонозбиральної техніки, була необхідність забезпечення паралельності стебел льону на всіх етапах збирання. Оскільки під час переробки льону на коротке волокно такої вимоги до розташування стебел льону у стрічці (валку) немає, відповідно, можна спростити конструкцію льонобрального апарата, чим зменшити його металомісткість. Тому, актуальним завданням $\epsilon$ обгрунтування конструкції нового льонобрального апарата, який би забезпечував лише брання льону, а також дослідження його роботи.

Аналіз останніх досліджень. У переважній більшості льонозбиральна техніка містить пасові льонобральні апарати різної конструкції $[1,2]$. Більшість наукових досліджень провідних науковців у галузі льонарства присвячена теоретичному обгрунтуванню конструкції та параметрів саме цих льонобральних апаратів [3 - 7]. Пасові льонобральні апарати забезпечують високу якість збирання льону та паралельність стебел у стрічці. Але ці льонобральні апарати є громіздкими, мають складну конструкцію та привод. Застосовувати льонозбиральну техніку з такими льонобральними апаратами для збирання льону, що буде перероблений на коротке волокно, є недоцільним. У більшості господарств для збирання льону, що призначений для переробки на коротке волокно, використовують зернозбиральні комбайни. Різальний механізм зернозбиральних комбайнів при цьому часто виходить 3 ладу, оскільки у стеблах льону міститься волокно. Крім того, у стерні після зрізування льону, залишається волокно, яке втрачається. Тому необхідно льон витягувати із грунту, а не зрізувати. Таким чином, доцільно застосовувати зернозбиральні комбайни 3 льонобральним апаратом замість різального механізму, ніж спеціалізовану льонозбиральну техніку. Таке використання зернозбиральної техніки суттєво здешевить вирощування та збирання льону i виробникам немає необхідності закупляти спеціалізовану техніку. Розробка нової конструкції льонобрального апарата потребує грунтовних теоретичних та експериментальних досліджень 3 обгрунтування його параметрів.

Формування цілей роботи. Мета дослідження - теоретично дослідити процес брання льону конічно-дисковим льонобральним апаратом.

Основна частина. Дослідимо переміщення рослини льону, що защемлена між конічними дисками льонобрального апарата $[8,9]$, від початку іï витягування із грунту до моменту контакту стебла із зубцем очисної планки, тобто виштовхування стебла льону із міждискового простору. Нехай, усі рослини льону мають однакові параметри та фізико-механічні властивості, а також розташовані у рядку на відстані $s$ одна від одної. Розглянемо випадок, коли у міждисковий простір надходять прямостоячі рослини льону лише 3 одного рядка, причому стебла льону розташовані в площині П контакту двох конічних дисків основами меншого радіуса $r$ (рис. 1 ).

Нехай, у початковий момент стебло прямостоячого льону защемлене між конічними дисками в площині П у точці $A$ (рис. 1, положення I). Відповідно, стебло защемлене між конічними дисками на висоті $l_{3}$ над поверхнею грунту, що рівна висоті встановлення конічно-дискового льонобрального 
апарата $l_{3}=h$ (де $h$ - відстань від осі обертання дисків до поверхні грунту, м), а також рівна довжині стебла $l_{c}$ (де $l_{c}$ - довжина частини стебла льону від поверхні грунту до місця защемлення стебла між конічними дисками (точка $A$ ), м), тобто $l_{3}=l_{c}=h$.

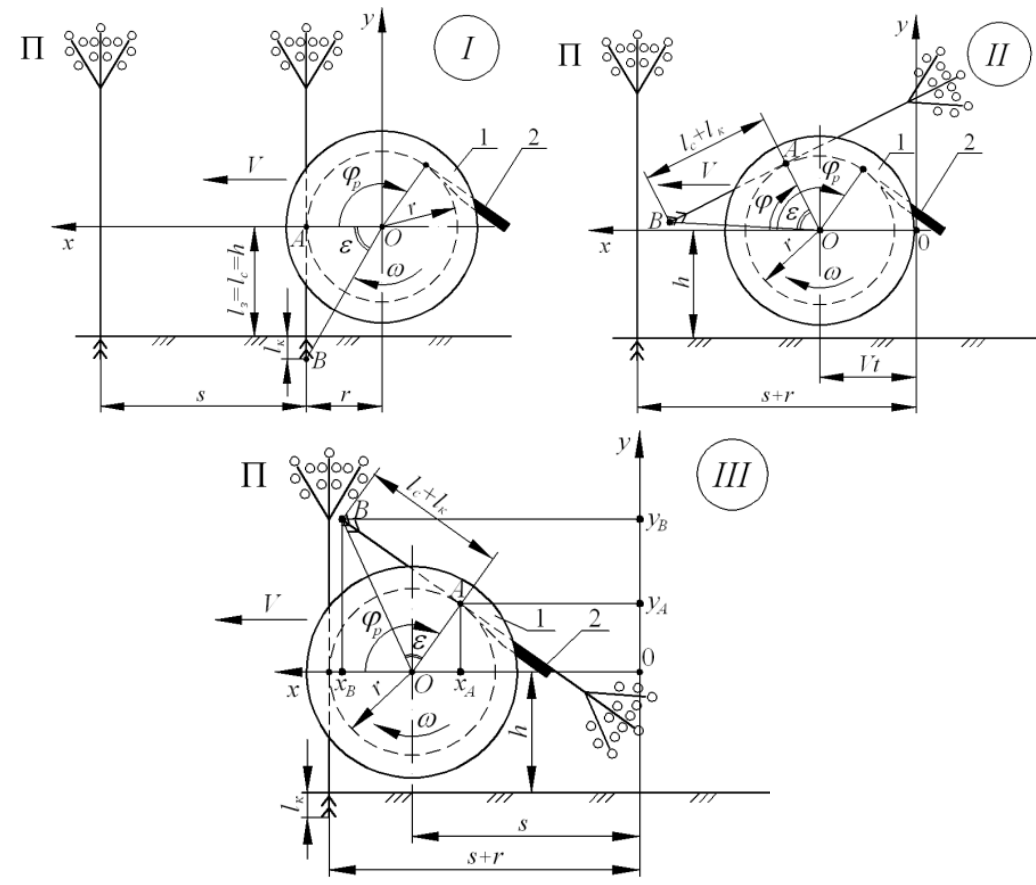

1 - конічні диски; 2 - зубець очисної планки (I- льон в момент защемлення між дисками; $I I$ - льон під час обертання з дисками; $I I I$ - льон виходить із міждискового простору)

Рисунок 1 - Схеми до пояснення переміщення рослини льону, що защемлена між конічними дисками

Защемлене між дисками у точці $A$ стебло льону внаслідок обертання дисків витягується із грунту та обертається разом із ними. Нехай, після витягування із грунту стебло льону залишається прямолінійним, тобто не згинається. Складемо рівняння руху точки $A$, що характеризує переміщення стебла льону під час його обертання разом з конічними дисками в процесі брання. Розташуємо нерухому систему координат $x O y$ у площині П контакту конічних дисків (рис. 1 , положення $I$ ). Причому початок координат системи $x O y$ розташовано у площині П на осі обертання дисків у момент початкового контакту дисків зі стеблом (рис. 1, положення I). Вісь $x$ спрямуємо горизонтально вздовж напрямку руху льонозбирального агрегата полем. Вісь $y$ спрямуємо вертикально вверх. Нехай льонозбиральний агрегат рухається полем вздовж рядка льону з постійною швидкістю $V$. Конічні диски бральних секцій розташовані на горизонтальному валу, який обертається зі сталою кутовою швидкістю $\omega$. Позначимо радіус дисків більшої основи через $R$, а радіус дисків меншої основи $-r$. Кут $\varphi$ повороту дисків починаємо відраховувати від початкового положення точки $A$ у напрямку обертання дисків. Враховуючи зазначене, для випадку $l_{c}=h$ рівняння переміщення точки $A$ стебла під час обертання з дисками матимуть вигляд:

$$
\left.\begin{array}{l}
x_{A}=V t+r \cos \varphi \\
y_{A}=r \sin \varphi ;
\end{array}\right\}
$$

де $x_{A}, y_{A}$ - координати точки $A$, відповідно, по осі $x$ та осі $y$, м; $t$ - час, який змінюється в межах від 0 до $t_{p}, \mathrm{c} ; t_{p}$ - час повороту дисків на кут $\varphi_{p}, \mathrm{c} ; \varphi_{p}-$ кут, що визначає робочу зону дисків, рад.

Для випадку $l_{3}=l_{c}=h$ складемо рівняння переміщення вільного кінця (на рис. 1 у положеннях II та $I I I$ - це точка $B$ ) защемленого стебла льону під час обертання дисків, якщо вільний кінець має довжину $l_{c}=l_{\kappa}$ (де $l_{\kappa}$ - довжина кореня льону, який витягується із грунту без обриву, м). Із метою спрощення приймаємо, що стебло не згинається під час витягування із грунту і обертання з дисками, тобто залишається прямолінійним. Нехай, траєкторія руху точки $B$ стебла у грунті така, як начебто грунт не чинить опір переміщенню прямолінійного стебла під час його обертання з дисками. Задачу спрощуємо із тією метою, що у даному випадку необхідно встановити найбільший можливий “виліт" вільного кінця стебла льону (точка $B$ ) перед дисками. Такий “виліт” матиме місце, якщо стебло льону 
під час брання не згинається. Від величини “вильоту” вільного кінця стебла, що обертається 3 дисками, буде залежати його вплив на надходження наступних рослин у міждисковий простір.

Із прямокутного трикутника $\triangle O A B$ очевидно (рис. 1), що радіус опущений із точки $O$ до вільного кінця стебла $B$ буде рівний $O B^{2}=r^{2}+\left(l_{c}+l_{k}\right)^{2}$, а кут між гіпотенузою $O B$ та катетом $O A$ складатиме $\varepsilon=\arcsin \left[\frac{l_{c}+l_{\kappa}}{\sqrt{r^{2}+\left(l_{c}+l_{\kappa}\right)^{2}}}\right]$.

Таким чином, рівняння переміщення точки $B$ стебла матимуть вигляд:

$$
\left.\begin{array}{l}
x_{B}=V t+\sqrt{r^{2}+\left(l_{c}+l_{\kappa}\right)^{2}} \sin \left(\frac{\pi}{2}-\varepsilon+\varphi\right) ; \\
y_{B}=-\sqrt{r^{2}+\left(l_{c}+l_{\kappa}\right)^{2}} \cos \left(\frac{\pi}{2}-\varepsilon+\varphi\right) ;
\end{array}\right\}
$$

де $x_{B}, y_{B}-$ координати точки $B$ по осі $x$ та осі $y$, м; $\varepsilon$ - кут між радіусом опущеним із точки $O$ до вільного кінця стебла $B$ та радіусом опущеним із точки $O$ до точки $A$ стебла, рад.

Для випадку $l_{3}=l_{c}=h$ траєкторії точок $A$ та $B$ стебла, побудовані за рівняннями (1) та (2), зображені на рис. 2. Визначимо найбільшу величину “вильоту” вільного кінця стебла льону під час обертання разом із дисками, тобто найбільше переміщення точки $B$ стебла вздовж осі $x$ (рис. 3, a). $\mathrm{У}$ першому рівнянні системи (2) введемо позначення $A=\left(r^{2}+\left(l_{c}+l_{\kappa}\right)^{2}\right)^{1 / 2}$ та врахуємо, що $\varphi=\omega t$ :

$$
x_{B}=V t+A \sin \left(\frac{\pi}{2}-\varepsilon+\omega t\right) \text {. }
$$
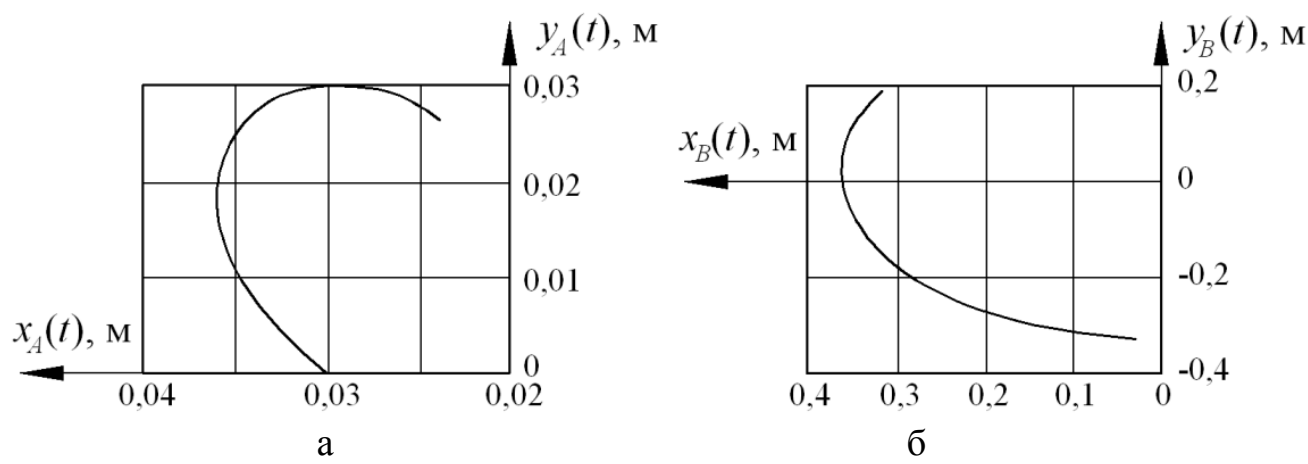

Рисунок 2 - Траєкторії точок $A$ (а) та $B$ (б) стебла, що защемлене між дисками, у випадку $l_{c}=h$ $\left(V=0,833 \mathrm{м} / \mathrm{c} ; r=0,03 \mathrm{м} ; l_{c}=0,3 \mathrm{м} ; l_{\kappa}=0,03 \mathrm{~m} ; s=0,04 \mathrm{м} ; \omega=45\right.$ рад. $/ \mathrm{c} ; t_{p}=0,047 \mathrm{c} ; \varepsilon=1,48$ рад.)

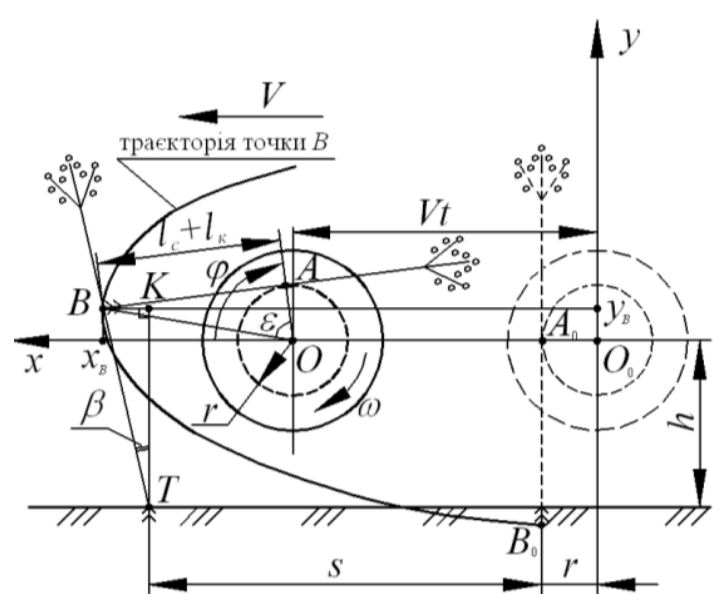

a

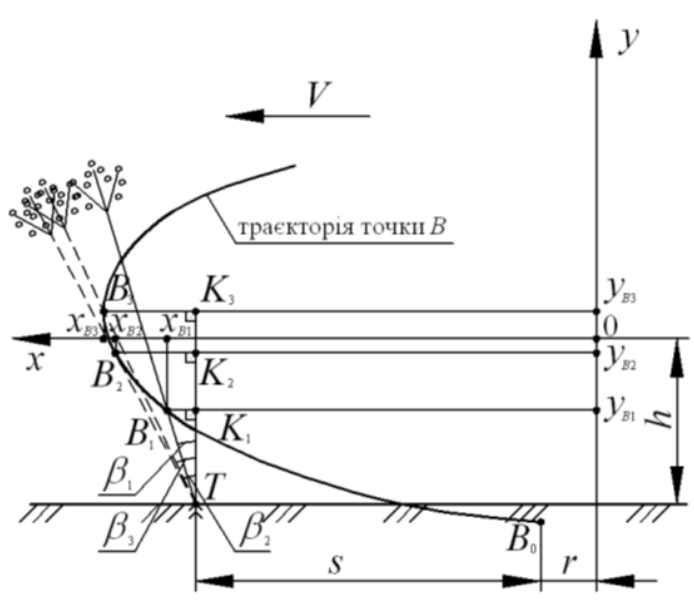

6

Рисунок 3 - Схеми до визначення “вильоту” $x_{B}$ вільного кінця стебла вибраного льону (а) та кута $\beta$ відхилення стебла невибраного льону від вертикального положення (б)

Здійснимо тригонометричні перетворення у рівнянні (3): 


$$
x_{B}(t)=V t+A \cos \varepsilon \cos (\omega t)+A \sin \varepsilon \sin (\omega t) .
$$

Знайдемо похідну від функції $x_{B}(t)$ за $t$ та прирівняємо іï до нуля:

$$
V-A \omega \cos \varepsilon \sin (\omega t)+A \omega \sin \varepsilon \cos (\omega t)=0 .
$$

Здійснимо тригонометричні перетворення у рівнянні (5) та введемо заміну $z=\operatorname{tg}(\omega t / 2)$ :

$$
\begin{gathered}
(V-A \omega \sin \varepsilon) \operatorname{tg}^{2}\left(\frac{\omega t}{2}\right)-2 A \omega \cos \varepsilon \operatorname{tg}\left(\frac{\omega t}{2}\right)+(V+A \omega \sin \varepsilon)=0 \\
(V-A \omega \sin \varepsilon) z^{2}-2 A \omega \cos \varepsilon z+(V+A \omega \sin \varepsilon)=0 .
\end{gathered}
$$

Корені рівнянь (6) та (7):

$$
\begin{gathered}
z_{1}=\frac{A \omega \cos \varepsilon+\sqrt{A^{2} \omega^{2}-V^{2}}}{V-A \omega \sin \varepsilon} \text { та } z_{2}=\frac{A \omega \cos \varepsilon-\sqrt{A^{2} \omega^{2}-V^{2}}}{V-A \omega \sin \varepsilon} . \\
t_{1}=\frac{2}{\omega} \operatorname{arctg}\left[\frac{A \omega \cos \varepsilon+\sqrt{A^{2} \omega^{2}-V^{2}}}{V-A \omega \sin \varepsilon}\right] \text { та } t_{2}=\frac{2}{\omega} \operatorname{arctg}\left[\frac{A \omega \cos \varepsilon-\sqrt{A^{2} \omega^{2}-V^{2}}}{V-A \omega \sin \varepsilon}\right] .
\end{gathered}
$$

Таким чином, найбільша величину “вильоту” вільного кінця стебла (точки $B$ ) вздовж осі $x$ :

$$
x_{B \max }=\max \left\{x_{B}\left(t_{1}\right) ; x_{B}\left(t_{2}\right)\right\} .
$$

Визначимо, на який кут $\beta$ відхилиться від вертикального положення у напрямку руху льонозбирального агрегата рослина льону, яка наступна у рядку за вибраною рослиною, внаслідок дії на неї вільного кінця стебла вибраної рослини, якщо прийняти, що стебло вибраної рослини залишається прямолінійним під час обертання з дисками. Необхідно зазначити, що якщо $x_{B \max } \leq s+r$, тоді відхилення стебла наступної рослини льону у рядку від вертикалі не буде, тобто $\beta=0$.

Розглянемо прямокутний трикутник $\triangle B K T$ (рис. 3 , а), де точка $B$ - це точка контакту вільного кінця стебла вибраної рослини 3 стеблом наступної невибраної рослини у рядку, причому у положенні, коли “виліт" вільного кінця стебла вибраної рослини найбільший, тобто за $x_{B}=x_{B \max }$. У трикутнику $\triangle B K T: B K=x_{B \max }-s-r$ та $K T=h+y_{B \max }$ (де $y_{B \max }-$ це координата точки $B$ стебла вздовж осі $y$ в момент часу $t_{x \max }$ (час $t_{x \max }$ визначається за виразом (10)), коли вільний кінець стебла досягає вздовж осі $x$ значення $\left.x_{B \max }\right)$. Враховуючи зазначене, матимемо:

$$
\operatorname{tg} \beta=\frac{B K}{K T}=\frac{x_{B \max }-s-r}{h+y_{B \max }} \text {, звідки } \beta=\operatorname{arctg}\left[\frac{x_{B \max }-s-r}{h+y_{B \max }}\right] \text {. }
$$

Що менше значення кута $\beta$, то кращі умови для брання льону конічно-дисковим льонобральним апаратом. Крім того, значне відхилення стебла льону від вертикального (початкового) положення 3 подальшим його коливанням, спричинятиме струшування супліддя, що, у свою чергу, зумовить обсипання насіння та насіннєвих коробочок, тобто втрату насіннєвої частини урожаю.

На рис. 3 (б) показано декілька положень невибраної рослини льону, що відхиляється від вертикального положення на кут $\beta$ внаслідок дії на неї вільного кінця стебла вибраного льону. Траєкторія вільного кінця стебла вибраного льону (точка $B$ ) залежить від параметрів стебла, висоти $h$ встановлення льонобрального апарата, довжини стебла $l_{c}$, на якій воно защемлене дисками, кутової швидкості обертання дисків $\omega$ та швидкості руху $V$ льонозбирального агрегата. Розглянемо відхилення стебла льону від вертикального положення протягом часу, коли вільний кінець (точка $B$ ) стебла вибраного льону переміщується своєю траєкторією на інтервалі від $x_{B}=s+r$ до $x_{B}=x_{B \max }$. межах цього інтервалу досягається найбільший кут $\beta=\beta_{\max }$ відхилення стебла невибраного льону від вертикального положення. Значення найбільшого кута $\beta_{\max }$ визначимо графічним методом. Для цього визначимо інтервал часу, протягом якого вільний кінець стебла вибраного льону буде переміщатися 
інтервалом від $x_{B}=s+r$ до $x_{B}=x_{B \max }$. Час $t_{s+r}$, за який вільний кінець стебла вибраного льону матиме координату по осі $x$ рівну $x_{B}=s+r$, також визначимо графічним методом. У момент часу $t_{s+r}$ вільний кінець стебла вибраного льону наблизиться до стебла невибраного льону, при цьому кут відхилення від вертикалі стебла невибраного льону буде $\beta=0$.

Побудуємо графік функції $x_{B}(t)$ (перше рівняння системи (2)). Графік будуємо на інтервалі часу від 0 до $t_{x \max }$. Визначимо із графіка, за якого значення часу $t=t_{s+r}$ функція $x_{B}\left(t_{s+r}\right)=s+r$ (рис. 4 , а). Час $t_{x \max }$, за який вільний кінець стебла вибраного льону досягне найбільшого “вильоту” вздовж осі $x$, визначається за виразами (10). У загальному випадку на інтервалі траєкторії вільного кінця стебла вибраного льону від $x_{B}=s+r$ до $x_{B}=x_{B \max }$ кут відхилення стебла невибраного льону від вертикального положення визначимо за виразом:

$$
\beta(t)=\operatorname{arctg}\left[\frac{x_{B}(t)-s-r}{h+y_{B}(t)}\right]=\operatorname{arctg}\left[\frac{V t+\sqrt{r^{2}+\left(l_{c}+l_{\kappa}\right)^{2}} \sin \left(\frac{\pi}{2}-\varepsilon+\omega t\right)-s-r}{h-\sqrt{r^{2}+\left(l_{c}+l_{\kappa}\right)^{2}} \cos \left(\frac{\pi}{2}-\varepsilon+\omega t\right)}\right],
$$

де $t \in\left(t_{s+r}, t_{x \max }\right)$.

Під час підстановки значень у залежність (12), необхідно приймати $l_{\kappa}=0$.

Побудуємо графік функції $\beta(t)$ на інтервалі часу від $t_{s+r}$ до $t_{x \max }$ (рис. 4, б). Із графіка визначимо найбільший кут відхилення стебла невибраного льону від вертикального положення $\beta_{\max }$ та час $t_{\beta \max }$, за який він досягається. Підставляючи значення часу $t_{\beta \max }$ у рівняння системи $(2)$, можна визначити координати вільного кінця стебла вибраного льону в момент, коли стебло невибраного льону відхилиться на найбільший кут $\beta_{\max }$ від вертикального положення.

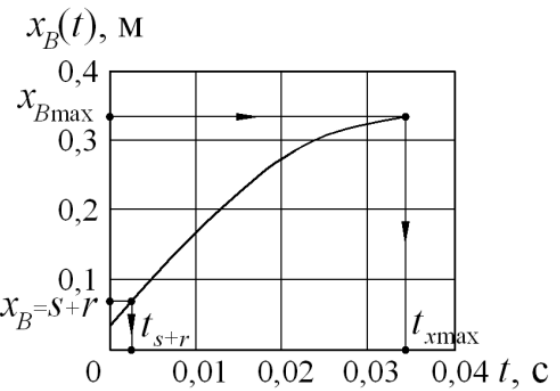

a

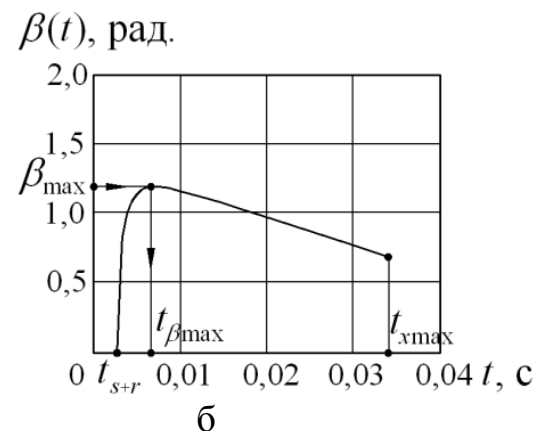

6

$$
\begin{gathered}
\text { Рисунок } 4-\text { Графіки функцій } x_{B}(t)(\mathrm{a}) \text { та } \beta(t)(\text { б) } \\
\left(r=0,03 \mathrm{м} ; h=0,3 \mathrm{м} ; l_{c}=0,3 \mathrm{м} ; l_{\kappa}=0,03 \mathrm{~m} ; V=0,833 \mathrm{~m} / \mathrm{c} ; \omega=45 \text { рад./c; } s=0,04 \mathrm{м}\right)
\end{gathered}
$$

Визначимо найбільший кут відхилення стебла невибраного льону від вертикального положення $\beta_{\max }$ та час $t_{\beta \max }$ при: $r=0,03 \mathrm{м} ; h=0,3 \mathrm{м} ; l_{c}=0,3 \mathrm{м} ; l_{\kappa}=0 ; V=0,833 \mathrm{~m} / \mathrm{c} ; \omega=45$ рад./c; $s=0,04$ м. У результаті розрахунків одержимо: $\varepsilon=1,471$ рад.; $t_{x \max }=0,034 \mathrm{c} ; t_{s+r}=0,0028 \mathrm{c} ; x_{B \max }=0,329 \mathrm{м}$; $y_{B \max }=0,019 \mathrm{м} ; \beta_{\max }=1,171$ рад.; $t_{\beta \max }=0,008$ с. Кут $\beta_{\max }=67$ град. $є$ значним, що може призвести до згину стебла та обсипання насіннєвої частину урожаю. Для зменшення значення кута $\beta_{\max }$ необхідно зменшувати довжину вільного кінця стебла вибраного льону, що можна забезпечити зменшенням висоти $h$ встановлення льонобрального апарата. Разом 3 тим, необхідно зазначити, що під час виведення залежностей приймалася низка припущень, зокрема про те, що вибране стебло не згинається під час обертання із дисками. Під час реального процесу брання вибране стебло льону буде згинатися як під час витягування із грунту (протягом витягування стебла із грунту на величину рівну довжині кореня $l_{\kappa}$ стебло буде огинати поверхню дисків), так і внаслідок контакту з наступними рослинами у рядку, якщо такий контакт матиме місце. Ймовірність контакту вільного кінця стебла вибраного льону із невибраним на його технічній довжині низька. Більшу ймовірність має контакт вільного кінця стебла вибраного льону із супліддям або розгалуженням невибраного льону. Внаслідок контакту із супліддям невибраного льону вільний кінець стебла вибраного льону буде також згинатися, оскільки супліддя буде чинити опір вільному кінцю стебла вибраного льону. Цей опір зумовлений тим, що у стеблостої льону розгалужені супліддя рослин переплетені, що забезпечує стійкість стеблостою. Тому значних відхилень невибраного льону від вертикального (початкового) положення внаслідок дії на нього вільних кінців стебел вибраного льону не буде. 
Вихід вибраного стебла льону із міждискового простору внаслідок дії зубця очисної планки відбувається за кута повороту конічних дисків $\varphi_{p}$. Кут $\varphi_{p}$ визначає робочу зону конічних дисків, коли защемлене стебло рухається разом $з$ дисками. Величина кута $\varphi_{p}$ має бути більшою за кут $\varphi_{\text {sum. }}$ повороту конічних дисків із защемленим стеблом, за якого відбувається витягування стебла із грунту, тобто $\varphi_{p}>\varphi_{\text {виm. }}$. Кут $\varphi_{\text {виm. }}$ визначається із врахуванням довжини $l_{\kappa}$ кореня льону та за умови, що стебло льону під час витягування не розтягується та огинає конічні диски на їх найменшому радіусі $r$ :

$$
\varphi_{\text {вum. }}=l_{\kappa} / r .
$$

Для визначення значення кута $\varphi_{p}$ обгрунтуємо положення встановлення зубця очисної планки відносно конічних дисків. Оскільки стебло льону під час обертання із дисками за прийнятим припущенням залишається прямолінійним, відповідно, доцільно, щоб зубець був встановлений по дотичній до дисків на їх радіусі $r$, тоді не буде мати місце згинання стебла під час виходу із міждискового простору. Спочатку розглянемо горизонтальне розташування зубця (рис. 5 , а). Цей варіант має недолік: горизонтальне розташування стебла льону на зубці очисної планки ускладнює його переміщення до наступних робочих органів і потребує встановлення додаткового робочого органу (бітера) для спрямування стебел вибраного льону із зубців очисної планки до шнека. Крім того, якщо $l_{c}+l_{\kappa}>r$ (тут $l_{c}=h$ ), тоді створюються несприятливі умови для надходження наступних рослин із рядка у міждисковий простір, оскільки наступні рослини будуть відгинатися у напрямку руху льонозбирального агрегата внаслідок дії на них гузиревої частини стебла вибраного льону.

Для усунення зазначеного недоліку зубець очисної планки необхідно розташовувати таким чином, щоб під час виходу вибраного льону із робочої зони дисків гузирева частина стебла не виходила за межу, що у площині рис. 5 (а) позначена лівою вертикальною штриховою лінією, яка проходять через крайню точку дисків вздовж горизонталі на їх радіусі $r$. Також необхідно, щоб кут встановлення зубця $\gamma$ забезпечував ковзання стебла вибраного льону поверхнею зубця до наступних робочих органів. Ковзання можливе, якщо кут встановлення зубця $\gamma$ рівний або більший за кут тертя $\varphi_{\text {mep. }}$ стебла по матеріалу зубця, тобто $\gamma \geq \varphi_{\text {mер. }}$ (рис. 5 , б). Таким чином, у випадку $l_{3}=l_{c}=h$ :

$$
\varphi_{p}=\pi-\left(\frac{\pi}{2}-\gamma\right)=\frac{\pi}{2}+\gamma
$$

Для того, щоб гузирева частина стебла вибраного льону не виходила за межу, що у площині рис. 5 (а) позначена лівою вертикальною штриховою лінією, у момент виходу стебла з робочої зони конічних дисків необхідно, щоб виконувалася умова (рис. 5, б):

$$
r \geq\left(l_{c}+l_{\kappa}\right) \cos \gamma-r \sin \gamma .
$$

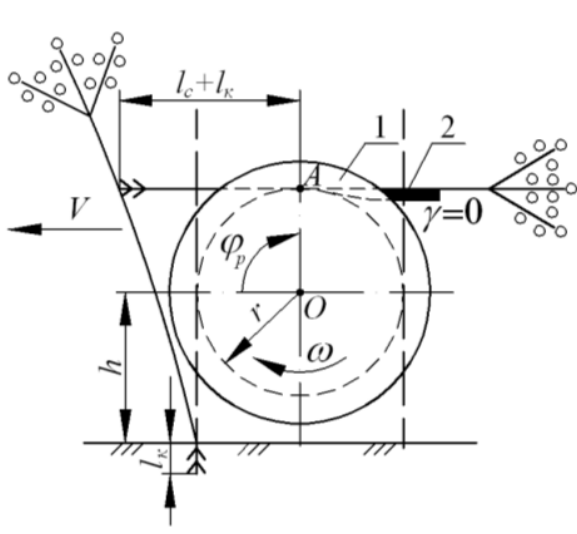

a

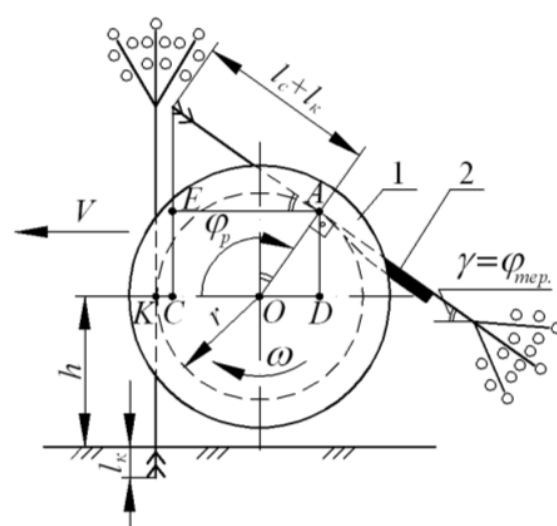

6

a - кут $\gamma=0 ;$ б - кут $\gamma=\varphi_{\text {тер. }}(1-$ конічні диски; 2 - зубець очисної планки $)$

Рисунок 5 - Схеми до обгрунтування кута $\gamma$ встановлення зубця очисної планки

Відповідно, необхідна висота $h$ встановлення льонобрального апарата над поверхнею грунту: 


$$
h \leq \frac{r(1+\sin \gamma)}{\cos \gamma}-l_{\kappa}, \text { якщо } \cos \gamma>0 .
$$

Переміщення льонозбирального агрегата вздовж рядка льону на відстань $s$ (де $s$ - відстань у рядку між двома сусідніми рослинами, м) має відбутися за час $t_{s}$, що більший часу $t_{p}$ повороту конічних дисків на кут $\varphi_{p}$. В іншому випадку матимуть місце несприятливі умови для брання льону, оскільки гузирева частина витягнутого із грунту стебла льону, що обертається защемленим разом із дисками, буде перешкоджати надходженню невибраного льону у простір між дисками (рис. 5, а). Таким чином, має виконуватися умова:

$$
t_{s}>t_{p} .
$$

Оскільки $t_{p}=\varphi_{p} / \omega$ та $t_{s}=s / V$, тоді із умови (17) визначимо кутову швидкість обертання дисків:

$$
\omega>\frac{V \varphi_{p}}{s}
$$

За значення кутової швидкості $\omega$, що задовольняє умову (18), конічні диски наблизяться до наступної рослини льону у рядку тоді, коли попереднє стебло льону, що защемлене і обертається із дисками, вийде з робочої зони дисків, яка визначається кутом $\varphi_{p}$.

Розглянемо випадки, коли стебло льону з рядка, що в площині П, у початковий момент защемлене між конічними дисками (на рис. 6 - це точка $A$ ) на висоті $l_{3} \neq h$ над поверхнею грунту.

Спочатку розглянемо випадок, коли $l_{3}<h$ (рис. 6 a, в). Цей випадок можливий, якщо стеблостій льону полеглий, тобто стебла льону відхилені у напрямку руху льонозбирального агрегата від вертикального положення на кут $\beta$, або льон у прямостоячому положенні не защемлений між дисками, а внаслідок дії на нього дисків відхиляється від вертикального положення на кут $\beta$ у напрямку руху льонозбирального агрегата полем і в такому положенні відбувається защемлення між дисками. При цьому решта рослин льону у рядку залишаються прямолінійними. У даному випадку не допустимо, щоб довжина стебла $l_{c}$, на якій відбувається защемлення, перевищувала технічну довжину стебла $l_{\text {mex. }}$. Оскільки, якщо $l_{3}>l_{\text {mex. }}$, тоді матимуть місце пошкодження та втрати насіннєвої частини врожаю внаслідок дії дисків. Таким чином, має виконуватися умова $l_{c} \leq l_{\text {mex. }}$.

У випадку $l_{3}<h$, рівняння руху точки $A$, що характеризує місце защемлення стебла дисками в площині П, та точки $B$ (вільний кінець стебла зі сторони гузирів) матимуть вигляд (рис. 6 , а):

$$
\left.\begin{array}{c}
x_{A}=V t+r \cos (\varphi-\beta) ; \\
y_{A}=r \sin (\varphi-\beta) ;
\end{array}\right\}
$$

У рівняннях (19) та (20) кут $\varphi=\omega t$, причому час $t$ змінюється в межах від 0 до $t_{p}=\varphi_{p \beta} / \omega$. Для випадку $l_{3}<h$ траєкторії точок $A$ та $B$ стебла льону зображені на рис. 7 та рис. 8 , а.

Для випадку, що розглядається, робоча зона конічних дисків буде визначатися кутом:

$$
\varphi_{p \beta}=\varphi_{p}+\beta
$$

Найбільше значення кута $\varphi_{p \beta}$, а також найбільша допустима висота $h$ встановлення конічнодискового льонобрального апарата будуть у випадку, якщо у початковий момент стебло буде защемлене у місці початку розгалуження супліддя (рис. 6, в), тобто, коли $l_{c}=l_{\text {mex. }}$. У цьому випадку:

$$
h-r \sin \beta=l_{\text {mex. }} \cos \beta \text {. }
$$

Знайдемо кут $\beta$ із рівняння (22): 


$$
\beta_{1,2}=2 \operatorname{arctg}\left[\frac{r \pm \sqrt{r^{2}-h^{2}+l_{\text {mex. }}^{2}}}{h+l_{\text {mex. }}}\right] .
$$

Значення кута $\beta$, за якого матимемо найбільший кут $\varphi_{p \beta}$ :

$$
\beta=\max \left\{\beta_{1} ; \beta_{2}\right\} .
$$

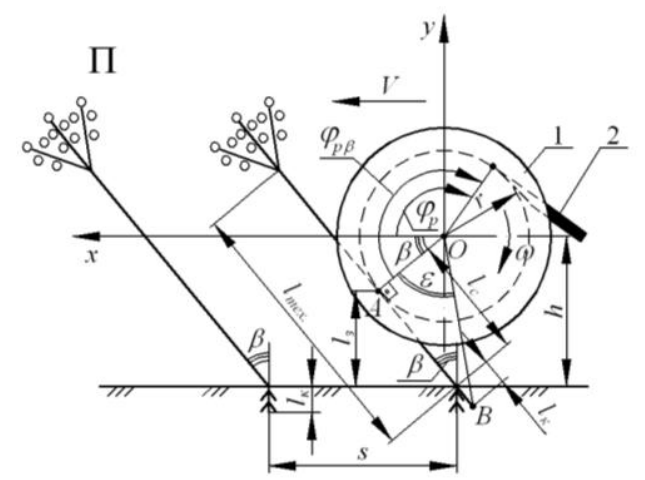

a

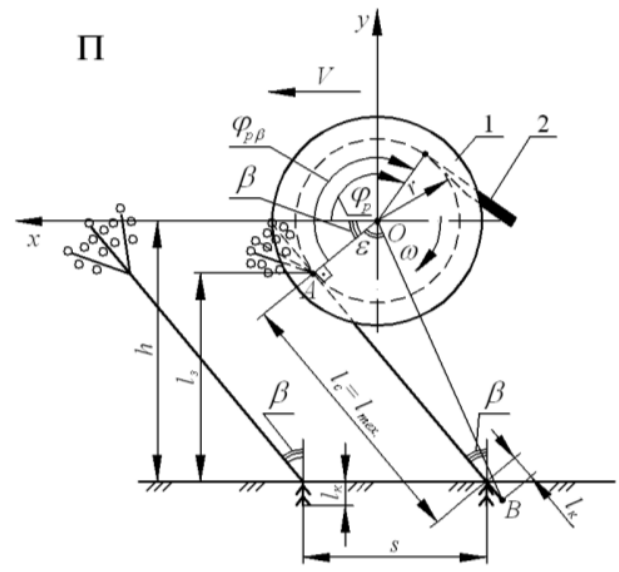

B

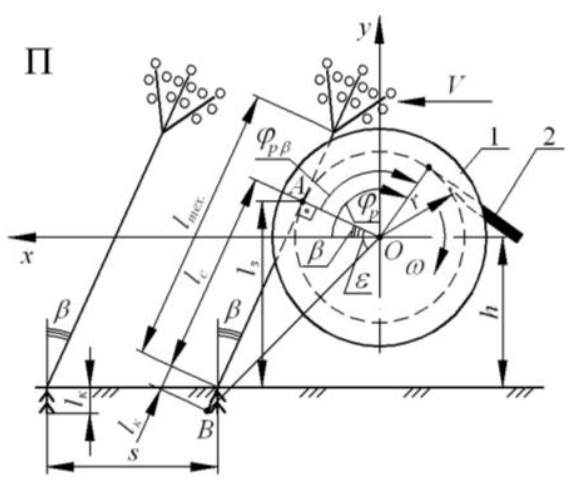

6

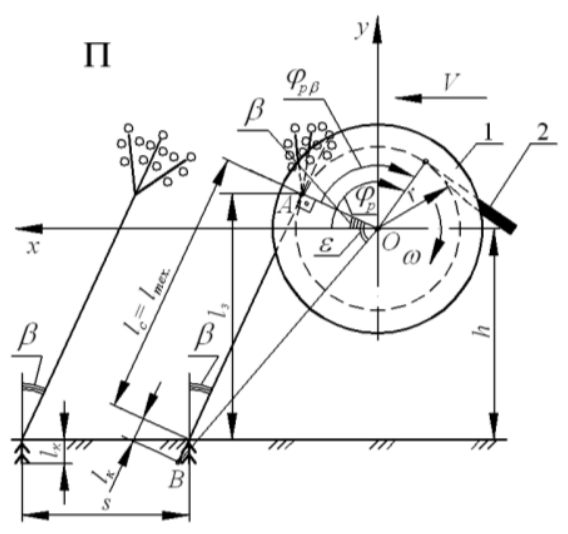

$\Gamma$

a, в $-l_{3}<h ; б, \Gamma-l_{3}>h(1-$ конічні диски; 2 - зубець очисної планки $)$

Рисунок 6 - Схеми переміщення стебла льону, що защемлене між дисками, у випадку $l_{3} \neq h$
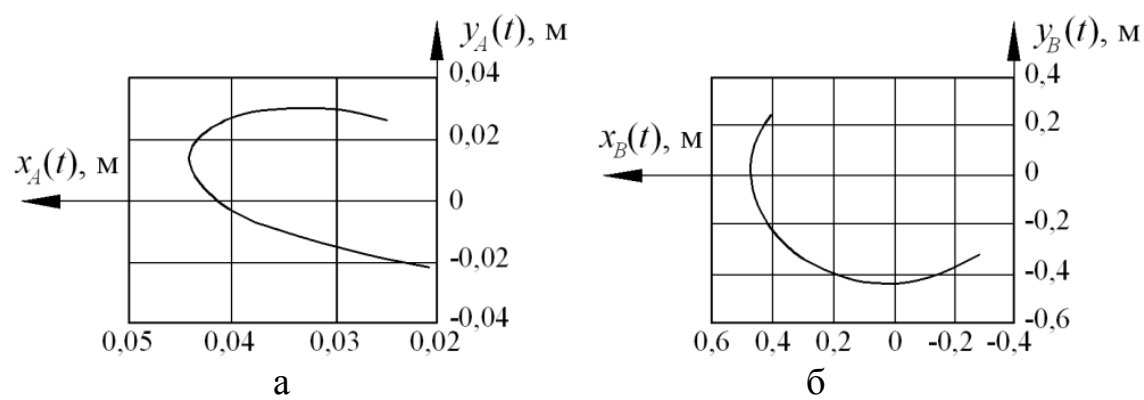

Рисунок 7 - Траєкторії точок $A$ (а) та $B$ (б) стебла льону, що защемлене між дисками, у випадку $l_{3}<h$ $\left(V=0,833 \mathrm{~m} / \mathrm{c} ; r=0,03 \mathrm{м} ; \gamma=\pi / 6\right.$ рад.; $h=0,3 \mathrm{~m} ; l_{\text {mex. }}=0,4 \mathrm{м} ; l_{c}=0,4 \mathrm{~m} ; l_{\kappa}=0,03 \mathrm{м} ; s=0,04 \mathrm{~m}$; $\omega=61$ рад./c; $t_{p}=0,047 \mathrm{c} ; \beta=0,801$ рад.; $\varepsilon=1,501$ рад.)

Визначений за виразом (24) кут $\beta$ - це найбільший допустимий кут відхилення стебел льону від вертикального положення, за якого можлива робота конічно-дискового льонобрального апарата, встановленого на висоті $h$, без втрат і пошкодження насіннєвої частини урожаю. При цьому значенні кута $\beta$ для випадку $l_{3}<h$ визначається найбільша допустима висота $h$ (рис. 6, в): 


$$
h \leq l_{\text {mex. }} \cos \beta+r \sin \beta .
$$

У випадку $l_{3}<h$, кутова швидкість обертання конічних дисків визначається з умови:

$$
\omega>\frac{V \varphi_{p \beta}}{s} \text { або } \omega>\frac{V\left(\varphi_{p}+\beta\right)}{s} .
$$

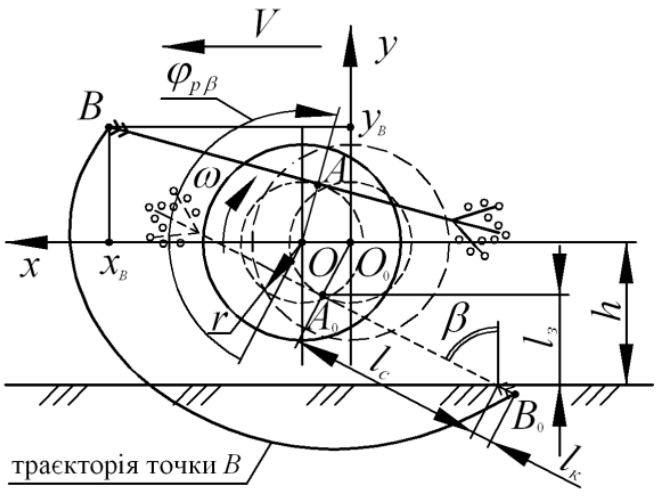

a

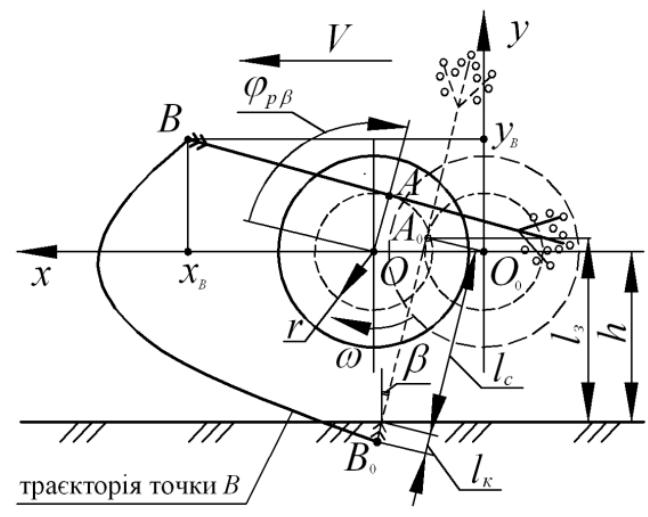

6

$$
\mathrm{a}-l_{3}<h ; 6,-l_{3}>h
$$

Рисунок 8 - Траєкторій переміщення стебла льону, що защемлене між дисками, у випадку $l_{3} \neq h$

Розглянемо випадок, коли $l_{3}>h$ (рис. 6 б, г). Цей випадок можливий, якщо стеблостій льону теж полеглий, але стебла льону відхилені від вертикального положення на кут $\beta$ у напрямку, що протилежний до напрямку руху льонозбирального агрегата. Для цього випадку рівняння руху точки $A$, що характеризує місце защемлення стебла дисками в площині П, та точки $B$ (вільний кінець стебла зі сторони гузирів) матимуть вигляд:

$$
\begin{aligned}
& \left.\begin{array}{l}
x_{A}=V t+r \cos (\varphi+\beta) \\
y_{A}=r \sin (\varphi+\beta)
\end{array}\right\} \\
& x_{B}=V t+\sqrt{r^{2}+\left(l_{c}+l_{\kappa}\right)^{2}} \sin \left(\frac{\pi}{2}-\varepsilon+\varphi+\beta\right) ; \\
& y_{B}=-\sqrt{r^{2}+\left(l_{c}+l_{\kappa}\right)^{2}} \cos \left(\frac{\pi}{2}-\varepsilon+\varphi+\beta\right) .
\end{aligned}
$$

У рівняннях (27) та (28) кут $\varphi=\omega t$, причому час $t$ змінюється в межах від 0 до $t_{p}=\varphi_{p \beta} / \omega$. Для цього випадку робоча зона конічних дисків буде визначатися кутом (рис. 6,6 ):

$$
\varphi_{p \beta}=\varphi_{p}-\beta
$$

Для випадку $l_{3}>h$ траєкторії точок $A$ та $B$ стебла зображені на рис. 8 , б та рис. 9 .
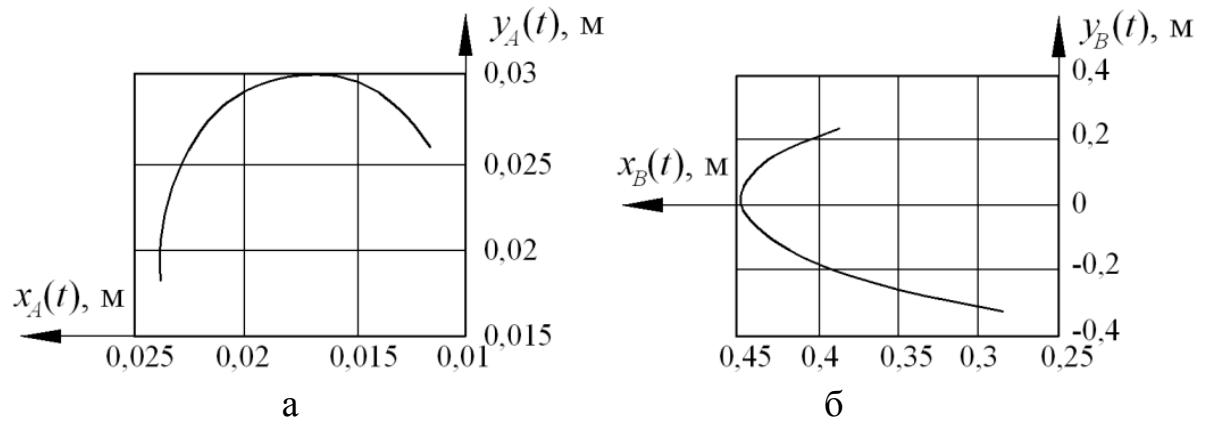

Рисунок 9 - Траєкторії точок $A$ (а) та $B$ (б) стебла льону, що защемлене між дисками, у випадку $l_{3}>h\left(V=0,833 \mathrm{~m} / \mathrm{c} ; r=0,03 \mathrm{м} ; \gamma=\pi / 6\right.$ рад.; $h=0,3 \mathrm{~m} ; l_{\text {mex. }}=0,4 \mathrm{~m} ; l_{c}=0,4 \mathrm{м} ; l_{\kappa}=0,03 \mathrm{~m} ; s=$ $0,04 \mathrm{м} ; \omega=45$ рад./c; $t_{p}=0,032 \mathrm{c} ; \beta=0,651$ рад.; $\varepsilon=1,501$ рад.) 
$\mathrm{У}$ цьому випадку, чим більше значення кута $\beta$, тим менше значення кута $\varphi_{p \beta}$, що визначає робочу зону конічних дисків. Разом з тим, має виконуватися умова $\varphi_{p \beta} \geq \varphi_{\text {вит. }}$. Для забезпечення виходу вибраного стебла льону з робочої зони дисків до надходження туди наступної рослини, кутову швидкість $\omega$ дисків необхідно визначати при $\beta=0$ з умови (18), оскільки тоді величина кута $\varphi_{p \beta}$ буде найбільшою. Якщо стеблостій полеглий, тоді льонозбиральний агрегат з конічно-дисковим льонобральним апаратом необхідно спрямовувати у напрямку, що протилежний напрямку відхилення стебел льону від вертикального положення на кут $\beta$, тоді матимемо $l_{3}>h$. Саме у випадку $l_{3}>h$ будуть створені найбільш сприятливі умови для брання льону.

Висновки. У результаті теоретичного дослідження процесу брання льону конічно-дисковим льонобральним апаратом отримано умови для обгрунтування раціональних параметрів апарата в залежності від стану стеблостою льону та його параметрів. Зокрема, отримано умови для визначення кутової швидкості обертання конічних дисків та висоти встановлення льонобрального апарата. Також отримано рівняння, що описують траєкторії руху частин стебла вибраного льону у конічнодисковому льонобральному апараті.

1. Хайлис Г. А. Льноуборочные машины / Г. А. Хайлис, Н. Н. Быков, В. Н. Бухарин и др. - М.: Машиностроение, 1985. -232 с.

2. Шейченко В. О. Обгрунтування параметрів та режиму роботи льонобрального апарата з поперечними рівчаками: дис... канд. техн. наук: 05.05.11 / Шейченко Віктор Олександрович; Український НДІ випробування та прогнозування техніки і технологій для сільськогосподарського виробництва ім. Леоніда Погорілого (УКРНДІПВТ ім. Л.Погорілого). Дослідницьке, 2006. - $173 \mathrm{c.}$

3. Налобіна О. О. Механіко-технологічні основи процесів взаємодії робочих органів льонозбирального комбайна 3 рослинним матеріалом: дис. ... д-ра техн. наук: 05.05.11 / Налобіна Олена Олександрівна; Луцький держ. техн. ун-т. - Луцьк, 2008. $-476 \mathrm{c}$

4. Foulk, J. A., Akin, D. E., \& Dodd, R. B. (2003). Fiber flax farming practices in the Southeastern United States. Crop Management, 2 (1). Available at https://doi.org/10.1094/CM-2003-0124-01-MG

5. Hall L. M., Booker H., Siloto R. M. P., Jhala A. J., Weselake R. J. (2016): Flax (Linum usitatissimum L.). Industrial Oil Crops, 157-194. Available at https://doi.org/10.1016/B978-1-893997-98-1.00006-3

6. Mańkowski, J., Maksymiuk, W., Spychalski, G., Kołodziej, J., Kubacki, A., Kupka, D., \& Pudełko, K. (2017). Research on new technology of fiber flax harvesting. Journal of Natural Fibers, 15 (1), 53-61.

7. Nilsson D. (2006). Dynamic simulation of the harvest operations of flax straw for short fibre production - Part 1. Journal of Natural Fibers, 3 (1), 23-34.

8. Патент №125964 (Україна), МПК A01D45/06, A01D41/14. Льонобралка конічно-дискова / Дударєв I.M.; Заявлено 29.01.2018; Опубл. 25.05.2018; Бюл. № 10.

9. Патент №126578 (Україна), МПК А01D45/06. Конічно-дисковий льонобральний апарат / Дударєв I.М.; Заявлено 29.01.2018; Опубл. 25.06.2018; Бюл. № 12.

\section{REFERENCES}

1. Khailys, H. A., Bykov, N. N., Bukharyn, V. N. (1985). Lnouborochnye mashyny, - M.: Mashynostroenye, 232.

2. Sheichenko, V. O. (2006). Obgruntuvannia parametriv ta rezhymu roboty lonobralnoho aparata z poperechnymy rivchakamy: dys... kand. tekhn. nauk: 05.05.11 / Sheichenko Viktor Oleksandrovych; Ukrainskyi NDI vyprobuvannia ta prohnozuvannia tekhniky i tekhnolohii dlia silskohospodarskoho vyrobnytstva im. Leonida Pohoriloho (UKRNDIPVT im. L.Pohoriloho), Doslidnytske, 173.

3. Nalobina, O. O. (2008). Mekhaniko-tekhnolohichni osnovy protsesiv vzaiemodii robochykh orhaniv lonozbyralnoho kombaina z roslynnym materialom: dys. ... d-ra tekhn. nauk: 05.05.11 / Nalobina Olena Oleksandrivna; Lutskyi derzh. tekhn. un-t, Lutsk, 476.

4. Foulk, J. A., Akin, D. E., \& Dodd, R. B. (2003). Fiber flax farming practices in the Southeastern United States. Crop Management, 2 (1). Available at https://doi.org/10.1094/CM-2003-0124-01-MG

5. Hall L. M., Booker H., Siloto R. M. P., Jhala A. J., Weselake R. J. (2016): Flax (Linum usitatissimum L.). Industrial Oil Crops, 157-194. Available at https://doi.org/10.1016/B978-1-893997-98-1.00006-3

6. Mańkowski, J., Maksymiuk, W., Spychalski, G., Kołodziej, J., Kubacki, A., Kupka, D., \& Pudełko, K. (2017). Research on new technology of fiber flax harvesting. Journal of Natural Fibers, 15 (1), 53-61.

7. Nilsson D. (2006). Dynamic simulation of the harvest operations of flax straw for short fibre production - Part 1. Journal of Natural Fibers, 3 (1), 23-34.

8. Dudarev, I. M. (2018). Lonobralka konichno-dyskova. UA Patent №125964, filed January 29, 2018, and issued May 25, 2018.

9. Dudarev, I. M. (2018). Konichno-dyskovyi lonobralnyi aparat. UA Patent №126578, filed January 29, 2018, and issued June 25, 2018.

Дударев И.Н., Хомыч А.В., Герасымык-Чернова Т. П. Теоретическое исследование процесса теребления льна конусно-дисковым льнотеребильным аппаратом.

Распространенные ременные льнотеребильные аппараты обеспечивают параллельность стеблей в ленте льна, но имеют сложную конструкцию. При переработке льна на короткое волокно в соответствии с новыми технологиями нет необходимости обеспечивать параллельность стеблей в ленте. Для уборки льна можно использовать конусно-дисковый льнотеребильный аппарат простой конструкции, условия, для обоснования параметров которого (угловой скорости и 
высоты установки дисков), получены в статье. Получены уравнения, описывающие траектории движения стебля в процессе теребления.

Ключевые слова: лен-долгунец, лен масличный, теребление льна, льнотеребильный аппарат, уборка льна, льноуборочная техника.

I. Dudarev. A. Khomych. T. Gerasymyk-Chernova. Theoretical study of the flax pulling process by conical-disc flax pulling mechanism.

Flax is mainly grown to produce a long flax fibre. Therefore, during harvesting, it is important to ensure the parallelism of flax stems in the band, as it is necessary for subsequent technological operations. The most common are belt flax pulling mechanisms. A large number of scientific studies of leading scientists in the field of flax are devoted to the theoretical justification of the design and parameters of these flax-pulling mechanisms. These flax pulling mechanisms provide high quality flax and parallelism of the stems in the flax band. But these flax pulling mechanisms are bulky, have a complicated structure and drive. During the processing of flax into a short flax fibre according to new technologies, there is no need for the stems in the tape to be parallel, even damage to the stems and their rupture is allowed. Thus, for flax harvesting, which is processed into a short flax fibre, it is possible to use flax pulling mechanisms of a simpler design, which should provide only the pulling of all flax plants from the soil. In most farms, grain harvesters are used to harvest flax, which is intended for processing on short fibers. The cutting mechanism of grain harvesting combines often fails, since flax contains fibers. In addition, in the stubble after cutting the flax, the fiber that is lost is left. Therefore, it is necessary to pull flax from the soil, and cutting flax is not desirable. Therefore, research towards the development of simple design of flax pulling mechanism is relevant. Accordingly, the aim of the study is to justify design parameters of conical-disc flax pulling mechanism. The theoretical study of the flax pulling process with a new conical-disc flax pulling mechanism having a simple design allowed us to obtain the conditions for substantiating its rational parameters, depending on the state and parameters of flax. Conditions for determining the angular velocity and the height of the installation of disks and equations describing the trajectories of motion of parts of the flax stem during pulling process are obtained.

Keywords: fiber flax, linseed, flax pulling process, flax pulling mechanisms, flax harvesting, flax harvesting machines.

АВТОРИ:

ДУДАРСВ Ігор Миколайович, доктор технічних наук, доцент, професор кафедри технологій і обладнання переробних виробництв, Луцький національний технічний університет, i_dudarev@ukr.net

ХОМИЧ Анатолій Васильович, кандидат технічних наук, в.о. директора, Любешівський технічний коледж Луцького НТУ, chomicht@ukr.net

ГЕРАСИМИК-ЧЕРНОВА Тетяна Павлівна, вчитель-методист, заступник директора 3 навчальної роботи, Любешівський технічний коледж Луцького НТУ.

АВТОРЫ:

ДУДАРЕВ Игорь Николаевич, доктор технических наук, доцент, профессор кафедры технологий и оборудования перерабатывающих производств, Луцкий национальный технический университет, i_dudarev@ukr.net

ХОМЫЧ Анатолий Васильевич, кандидат технических наук, и.о. директора, Любешовский технический колледж Луцкого НТУ, chomicht@ukr.net

ГЕРАСЫМЫК-ЧЕРНОВА Татьяна Павловна, учитель-методист, заместитель директора по учебной работе, Любешовский технический колледж Луцкого НТУ.

\section{AUTHORS:}

Igor DUDAREV, Doctor of Technical Sciences, Professor of Department of Technologies and Equipment of Processing Industries, Lutsk National Technical University, i_dudarev@ukr.net

Anatoliy KHOMYCH, Candidate of Technical Sciences, Acting Director, Liubeshiv Technical College, chomicht@ukr.net

Tatiana GERASYMYK-CHERNOVA, Teacher-Methodist, Deputy Director of Education, Liubeshiv Technical College. 